\title{
Hanne Bruun og Kirsten Frandsen (eds.): Underholdende tv. Aarhus: Aarhus Universitetsforlag. 2010.
}

\author{
Thomas Bjørner
}

MedieKultur 2011, 51, 192-194

Published by SMID | Society of Media researchers In Denmark | www.smid.dk The online version of this text can be found open access at www.mediekultur.dk

$X$-factor zap Vild med dans zap Normalerweize zap Hvem vil vere millioncer zap Den blinde vinkel zap Spise med Price zap Kender du typen zap Liebhaverne zap håndboldkampen AG København-BSV. Alle kender til underholdningsprogrammer på tv, og hvor man i større eller mindre grad har oplevet følelsen af at være godt underholdt. Måske man har siddet en fredag aften sammen med familien og set $X$-factor, diskuteret deltagernes præstationer og måske sms-stemt på den, man rettelig synes bør vinde. Bogen Underholdende tv sætter fokus på et alvorligt emne - nemlig underholdning i tv. Bogen tager udgangspunkt i dansk tv-underholdning i perioden 1998-2008 og konstaterer, at underholdningen i prime time på dansk tv's ni mest sete kanaler er vokset fra 17 \% i 1998 til 22-23 \% i 2008. Bogens grundlæggende optik er, at underholdning og det underholdende er en relation mellem et medieudspil og en modtager, der er præget af bestemte kontekstuelle forhold. Konteksten skal forstås som både de vilkår, hvorunder tv bruges og produceres, og de psykologiske, sociale og kulturelle konsekvenser dette kan have. Bogen har således både et afsender- og modtagerperspektiv, men der vægtes i høj grad også et tekstanalytisk perspektiv. Det mest centrale udgangspunkt for bogen er, at tv-underholdning er en relation mellem en modtager og et tekstligt, æstetisk udspil fra mediet. Således giver bogen gennem en række analyser af udvalgte danske underholdningsprogrammer et bud på, hvad underholdning er, og i hvilken kontekst programmerne indgår.

Bogens første artikel sætter fokus på definitionsmæssige problemstillinger og konkluderer netop, at underholdning ikke er enten en tekstkategori eller en bestemt oplevelse, 
men et relationelt fænomen. Der sættes et særligt fokus på at geninddrage tekstens rolle $i$ analysen af underholdning. Med inspiration fra Ellen Dissanayakes kunstperspektiv (som beskæftiger sig med, hvor kunsten og æstetikken kommer fra) er en initierende definition af tv-underholdning "en form for ualmindeliggørelse af 'noget'" (s. 27). Det er en grundlæggende betragtning, at man uden større problemer kan overføre Dissanayakes kunstæstetiske perspektiv til populærkulturen. Det er et interessant perspektiv, men måske er det ikke helt uproblematisk at overføre Dissanayakes perspektiv til tv-underholdning. Derfor peger bogens første artikel selv på en lang række forskellige perspektiver i en slags state of the art, hvor tv-underholdning både kan ses som kanaler, som sprog og som miljøer, for nu at bruge Meyrowitz' inddelinger af forskellige perspektiver i medieforskningen.

Bogens andet bidrag er fra Anne Jerslev, som har analyseret Vild med dans. Det metodiske grundlag er 16 interviews med kvindelige seere af Vild med dans. Analysen viser, at netop Vild med dans kan etablere en lystfyldt æstetisk oplevelse for sine seere. Man hygger sig og føler sig godt underholdt.

I bogens tredje bidrag har Kirsten Frandsen set på hhv. håndbold- og fodboldseere. Undersøgelsen baseres på 14 kvalitative interviews med $\mathrm{i}$ alt 19 personer (10 kvinder og 9 mænd). Konklusionen er, at tv-seeren i høj grad selv er med til at producere sin egen underholdning. Derudover viser analysen, at underholdning i sportstransmissioner både kan dreje sig om afslappende nydelse og et følelsesmæssigt kick gennem en situativ oplevelse af spænding.

I de følgende tre bidrag er der analyser af livsstilsprogrammer, rejseprogrammer og humoristiske tv-reklamer. I Christa Lykke Christensens bidrag om tv's livsstilsprogrammer (som oftest sendes på hverdagsaftener) er det en væsentlig pointe, at disse programmer gør en dyd ud af at gøre det meget ordinære ekstraordinært. Derved kan det, som foregår på skærmen, opleves som en simuleret virkelighed. Mange livsstilsprogrammer har karakter af eksperimenter - som ender godt. Artiklen konkluderer afsluttende, at underholdningsværdien måske ligger i, at seeren faktisk føler sig ganske godt hjemme på en behagelig måde i dette, deres andet, imaginære og uforpligtende hverdagslige rum, som de tilbydes at træde ind i på en helt almindelig hverdagsaften.

Anne Marit Waade analyserer to udvalgte personlige rejsedokumentarprogrammer, nemlig Rejsen til verdens navle (med Troels Kløvedal som vært) og BBC-serien Michael Palin på verdens tag (med Michael Palin som vært). Artiklen konkluderer, at underholdning i tv har rødder og forbindelseslinjer til andre kulturelle felter. Seernes oplevelse af serierne og seriernes audiovisuelle æstetik er således ikke en isoleret størrelse. Anne Marit Waade argumenterer således gennem artiklen for, at rejseseriers udsigt tilfører programtypen særlig nydelsesfuld æstetik, blandt vha. værtsfunktionen, brug af musik, filmisk dvælende blik ved landskaber sammen med tv-mediets hurtige og skiftende blik.

Jørgen Stigel sætter i sin artikel fokus på humor i tv-reklamen, og hvordan humor forudsætter et aktivt samspil fra seeren. Humor fungerer således underholdende, hvis seeren oplever sig i stand til at levere det forventede kognitive indspil. Men artiklen beskriver også, 
hvordan humoristiske hensigter kan skabe problemer, i det omfang det humoristiske islæt og pointen ikke er integreret og klart forankret i sagen.

I Lothar Mikos' artikel beskrives, hvorledes tv-underholdning i dag handles som programmer og formater på et globalt tv-marked. I artiklen indgår en beskrivelse af nogle særlige træk ved tysk tv-underholdning og tyske formatadoptioner. En af konklusionerne er, at formatunderholdning i tysk tv ikke er særligt kreativ. Der satses primært på formater, der allerede har haft succes i andre lande. Derfor konkluderer forfatteren også, at tysk tv i høj grad er uden profil og har et dårligt ry i det internationale tv-landskab. Selvom artiklen ikke rummer samme æstetiske og tekstanalytiske tilgang som bogens øvrige artikler, og selvom det ikke beskrives eksplicit, så kommer man uundgåeligt til at tænke på tysk tv-underholdning indeholdende slagermusik i en slags fællessang på Bakken. Jo, der er så sandelig forskel på Danmark og Tyskland inden for tv-underholdning, og som artiklen beskriver, skyldes det en lang række faktorer, både historiske og samfundsmæssige.

Hanne Bruuns artikel sætter fokus på udviklingen i dansk tv-satire. Artiklen beskriver nogle af de forandringer, der er sket historisk, og hvordan kravene til både seerne og produktionskulturen har ændret sig. Seerne er således ikke længere blot seere, men også brugere og medproducenter.

I bogens sidste artikel beskriver Anja Bechmann, hvordan netop dette behov for kontakt med seerne har medført en integration mellem medieplatforme. En meget interessant konklusion er, at en af årsagerne til, at underholdningsværdien kan forsvinde, kan hænge sammen med typen af den simulation, egenproduktionen er for brugerne. Det vil sige, at når det bliver en del af et professionelt underholdningsprodukt, så ændrer simulationen fundamentalt karakter for de producerende brugere. Artiklen skal have et ekstra stort plus for en forsøgsvis skelnen mellem forskellige brugerproduktionsroller for medievirksomheder.

Det er bestemt på sin plads at sætte fokus på underholdning i tv - og tage afsæt i, hvad æstetikken gør i tv-underholdningen. Der er ingen tvivl om, at der har manglet forskning inden for dette felt. Bogen rummer nogle grundige analyser, men man savner måske lidt flere metodologiske, metodiske og teoretiske refleksioner og nyudviklinger.

Underholdende tv er hverken forlorent eller indholdsløst. Det er langt mere alvorligt, og som det også fremgår af indledningen, så er tv-underholdning mere end blot adspredelse eller kompensation, det har også en langt større sammenhængskraft i samfundet. Det giver bogen Underholdende tv et godt indblik i.

Thomas Bjørner

Lektor, PhD

Institut for Arkitektur, Design og Medieteknologi

Aalborg Universitet - København

tbj@create.aau.dk 